\title{
Effects of feeding level on nutrient digestibility and enteric methane production in growing goats (Capra hircus hircus) and Sika deer (Cervus nippon hortulorum)
}

\author{
Youngjun $\mathrm{Na}^{1}$, Dong Hua Li', Yongjun Choi ${ }^{1}$, Kyoung Hoon Kim ${ }^{2,3}$, and Sang Rak Lee ${ }^{1, *}$
}

\author{
* Corresponding Author: Sang Rak Lee \\ Tel: +82-2-450-3696, Fax: +82-2-455-1044, \\ E-mail: leesr@konkuk.ac.kr \\ 1 Department of Animal Science and Technology, \\ Konkuk University, Seoul 05029, Korea \\ ${ }^{2}$ Graduate School of International Agricultural \\ Technology, Seoul National University, Pyeongchang \\ 25354, Korea \\ ${ }^{3}$ Institute of Green Bioscience and Technology, Seoul \\ National University, Pyeongchang 25354, Korea \\ ORCID \\ Youngjun $\mathrm{Na}$ \\ https://orcid.org/0000-0002-4643-0191 \\ Yongjun Choi \\ https://orcid.org/0000-0002-5759-4108 \\ Kyoung Hoon Kim \\ https://orcid.org/0000-0002-4014-9390 \\ Sang Rak Lee \\ https://orcid.org/0000-0002-8905-0770
}

Submitted Sept 22, 2017; Revised Jan 11, 2018; Accepted Feb 14, 2018
Objective: Two experiments were conducted to determine the effects of feeding level on nutrient digestibility and enteric methane $\left(\mathrm{CH}_{4}\right)$ emissions in growing goats and Sika deer. Methods: Three growing male goats (initial body weight [BW] of $22.4 \pm 0.9 \mathrm{~kg}$ ) and three growing male deer (initial BW of $20.2 \pm 4.8 \mathrm{~kg}$ ) were each allotted to a respiration-metabolism chamber for an adaptation period of $7 \mathrm{~d}$ and a data collection period of $3 \mathrm{~d}$. An experimental diet was offered to each animal at one of three feeding levels (1.5\%, $2.0 \%$, and $2.5 \%$ of BW) in a $3 \times 3$ Latin square design. The chambers were used for measuring enteric $\mathrm{CH}_{4}$ emission. Results: Nutrient digestibility decreased linearly in goats as feeding level increased, whereas Sika deer digestibility was not affected by feeding level. The enteric production of $\mathrm{CH}_{4}$ expressed as $\mathrm{g} / \mathrm{kg}$ dry matter intake (DMI), $\mathrm{g} / \mathrm{kg}$ organic matter intake, and \% of gross energy intake decreased linearly with increased feeding level in goats; however, that of Sika deer was not affected by feeding level. Six equations were estimated for predicting the enteric $\mathrm{CH}_{4}$ emission from goats and Sika deer. For goat, equation 1 was found to be of the highest accuracy: $\mathrm{CH}_{4}(\mathrm{~g} / \mathrm{d})=6.2( \pm 14.1)+10.2( \pm 7.01) \times \mathrm{DMI}(\mathrm{kg} / \mathrm{d})+0.0048( \pm 0.0275) \times$ dry matter digestibility $(\mathrm{DMD}, \mathrm{g} / \mathrm{kg})-0.0070( \pm 0.0187) \times$ neutral detergent fiber digestibility (NDFD; $\mathrm{g} / \mathrm{kg})$. For Sika deer, equation 4 was found to be of the highest accuracy: $\mathrm{CH}_{4}(\mathrm{~g} / \mathrm{d})=-13.0( \pm 30.8)+29.4$ $( \pm 3.93) \times$ DMI $(\mathrm{kg} / \mathrm{d})+0.046(0.094) \times \mathrm{DMD}(\mathrm{g} / \mathrm{kg})-0.0363( \pm 0.0636) \times \mathrm{NDFD}(\mathrm{g} / \mathrm{kg})$.

Conclusion: Increasing the feeding level increased $\mathrm{CH}_{4}$ production in both goats and Sika deer, and predictive models of enteric $\mathrm{CH}_{4}$ production by goats and Sika deer were estimated.

Keywords: Capra hircus hircus; Cervus nippon hortulorum; Methane; Greenhouse Gas; Feeding Level

\section{INTRODUCTION}

Enteric methane $\left(\mathrm{CH}_{4}\right)$ production in ruminants is recognized as one of the major sources of greenhouse gas emissions associated with agriculture [1]. Although a large number of goats and Sika deer inhabit East Asia [2], few studies have estimated enteric $\mathrm{CH}_{4}$ production of goats and Sika deer. Enteric $\mathrm{CH}_{4}$ production by ruminants is generally influenced by various dietary factors such as the forage-to-concentrate ratio [3], carbohydrate type [2,4], forage processing [5], fat addition [6], and ionophore addition [7]. Fundamentally, because enteric methane production is a part of the energy utilization process of ruminants, the amount of feed intake has been suggested as the major factor driving enteric $\mathrm{CH}_{4}$ production. Changes of feed intake level affect passage rate and rumen fermentation characteristics and, thereby, can alter nutrient digestibility and $\mathrm{CH}_{4}$ production of the animal [8]. Therefore, the aims of the present study were i) to determine the effects of feeding level on nutrient digestibility and enteric $\mathrm{CH}_{4}$ production and ii) to estimate the for the respective enteric $\mathrm{CH}_{4}$ produc- 
tion prediction equations for growing goats and Sika deer.

\section{MATERIALS AND METHODS}

Experiments were conducted to determine the nutrient digestibility and enteric $\mathrm{CH}_{4}$ and $\mathrm{CO}_{2}$ emissions in goats (Capra hircus hircus) and Sika deer (Cervus nippon hortulorum) in accordance with the Institutional Animal Care and Use Committee of Konkuk University.

\section{Animals, diets, and experimental design}

Three growing male goats (initial body weight [BW] of $22.4 \pm$ $0.9 \mathrm{~kg}$ ) and three growing male deer (initial BW of $20.2 \pm 4.8$ $\mathrm{kg}$ ) were used in this study. Each animal was housed individually in a respiration-metabolism chamber as described by Li et al [9] for a diet adaptation period of $7 \mathrm{~d}$ and a data collection period of 3 days $[10,11]$. The same experimental diet was prepared and used for both goat and deer experiments (Table 1), and animals were randomly assigned to one of three feeding levels (1.5\%, $2.0 \%$, or $2.5 \%$ of BW), which were applied in a $3 \times 3$ Latin square design. Experimental diets were fed daily at $1100 \mathrm{~h}$, and water and mineral block (contained 3,250 $\mathrm{K} \mathrm{IU} / \mathrm{kg}$ vitamin A, $500 \mathrm{~K} \mathrm{IU} / \mathrm{kg}$ vitamin $\mathrm{D}, 2,500 \mathrm{IU} / \mathrm{kg}$ vitamin $\mathrm{K}, 200 \mathrm{mg} / \mathrm{kg}$ vitamin $\mathrm{B}_{1}, 200 \mathrm{mg} / \mathrm{kg}$ vitamin $\mathrm{B}_{2}, 250$ $\mu \mathrm{g} / \mathrm{kg}$ vitamin $B_{12}, 3,500 \mathrm{mg} / \mathrm{kg}$ niacin, $9,000 \mathrm{mg} / \mathrm{kg}$ choline chloride, 48,000 mg/kg methionine, $10,200 \mathrm{mg} / \mathrm{kg}$ glycine, $100 \mathrm{mg} / \mathrm{kg} \beta$-carotene, $254 \mathrm{~g} / \mathrm{kg}$ calcium, $38 \mathrm{~g} / \mathrm{kg}$ phosphorus, $4,000 \mathrm{mg} / \mathrm{kg}$ manganese, $9,050 \mathrm{mg} / \mathrm{kg}$ zinc, $4,500 \mathrm{mg} / \mathrm{kg}$ iron, $200 \mathrm{mg} / \mathrm{kg}$ iodine, $45 \mathrm{mg} / \mathrm{kg}$ cobalt, 11,000 mg/kg magnesium, 2,300 mg/kg copper, $92 \mathrm{mg} / \mathrm{kg}$ selenium) were freely accessible. Sampling unit was feces which collected daily $(n=3 d / a n i m a l)$. Total fecal samples were collected at $1000 \mathrm{~h}$ and immediately dried for subsequent chemical analysis. Digestibility coefficients were calculated by the following formula: nutrient digestibility $(\%)=[$ nutrient intake $(\mathrm{g})$ - nutrient in the fecal $(\mathrm{g})] /$ nutrient intake $(\mathrm{g}) \times 100$. Experimental unit was animal $(\mathrm{n}=3$ animals/ treatment).

Table 1. Ingredients and nutrient composition of experiment diets

\begin{tabular}{lc}
\hline Items & Experimental diet \\
\hline Ingredients (\%, DM basis) & \\
Ground corn & 25.5 \\
Soybean meal & 24.5 \\
Tall fescue, hay & 50.5 \\
Nutrient composition & \\
DM (\%) & 89.3 \\
OM (\% DM) & 92.1 \\
CP (\% DM) & 16.0 \\
NDF (\% DM) & 44.0 \\
GE (MJ/kg DM) & 15.9 \\
\hline
\end{tabular}

$\mathrm{DM}$, dry matter; OM, organic matter; $\mathrm{CP}$, crude protein; NDF, neutral detergent fiber; $G E$, gross energy.

\section{Chemical analysis}

Feed ingredients and fecal samples were analyzed in duplicate for dry matter $(\mathrm{DM})$, organic matter $(\mathrm{OM})$, crude protein $(\mathrm{CP})$, and ether extract as described by AOAC [12]. Neutral detergent fiber (NDF) was analyzed using heat stable $\alpha$-amylase (Sigma A3306; Sigma Chemical Co., St. Louis, MO, USA) according to the method described by Van Soest et al [13]. Gross energy (GE) was analyzed using a bomb calorimeter (C5000; IKA, Staufen, Germany).

\section{Gas production measurement}

A respiration-metabolism chamber system was used to measure enteric $\mathrm{CH}_{4}$ and $\mathrm{CO}_{2}$ production [9], and a gas flow meter (GFM57, Aalborg Instruments \& Controls Inc., Orangeburg, NY, USA) and a sample pump (Columbus Instruments, Columbus, $\mathrm{OH}, \mathrm{USA}$ ) were used to collect inlet and outlet gas samples. Collected gas samples were passed through a desiccant $\left(\mathrm{CaSO}_{4}\right)$ before the samples flew into the gas analyzer. A non-dispersive infrared gas analyzer (VA-3000; Horiba Stec Co., Kyoto, Japan) was used to analyze the concentrations of $\mathrm{CH}_{4}$ and $\mathrm{CO}_{2}$.

\section{Statistical analysis}

All variables were analyzed using SAS PROC MIXED (Version 9.2; SAS Institute Inc., Cary, NC, USA). The statistical model included treatment as a fixed effect and animal and period as random effects. The orthogonal polynomial contrast was tested using the CONTRAST statement to examine the linear and quadratic effects of feeding level on the response variables. Significant differences were declared at $p<0.05$, and trends were defined at $0.05 \leq p<0.10$. SAS PROC REG (Version 9.2; SAS Institute Inc., USA) was used to estimate simple and multiple linear equations. Equations were evaluated based on the root mean square error (RMSE), adjusted- $\mathrm{R}^{2}$, and the $\mathrm{p}$ value.

\section{RESULTS}

Dry matter intake (DMI) of both goats and Sika deer increased linearly $(\mathrm{p}<0.05)$ as feeding level increased (Table 2$)$. The DM, $\mathrm{OM}, \mathrm{CP}$, and neutral detergent fiber digestibility (NDFD) of goats decreased linearly $(\mathrm{p}<0.05)$ as the feeding level increased. However, the DM, OM, CP, and NDFD of Sika deer did not differ significantly among feeding level treatment groups.

In goats, enteric emission of $\mathrm{CH}_{4}$ expressed as $\mathrm{g} / \mathrm{d}$ and $\mathrm{g} / \mathrm{kg}$ $\mathrm{BW}^{0.75}$ increased linearly $(\mathrm{p}<0.05)$ with increasing feeding level (Table 3); however, when expressed as g/kg DMI, g/kg organic matter intake (OMI), and \% of gross energy intake (GEI), it decreased linearly $(\mathrm{p}<0.05)$ with increasing of feeding level. No difference in enteric $\mathrm{CH}_{4}$ production when expressed as $\mathrm{g} / \mathrm{kg}$ digested dry matter intake (DDMI) and $\mathrm{g} / \mathrm{kg}$ digested organic matter intake (DOMI) was observed among feeding 
Table 2. Effect of feeding levels on nutrient digestibility in goats (Capra hircus hircus) and Sika deer (Cervus nippon hortulorum)

\begin{tabular}{|c|c|c|c|c|c|c|}
\hline \multirow{2}{*}{ Items } & \multicolumn{3}{|c|}{ Feeding level ( $\%$ of BW) } & \multirow{2}{*}{ SEM } & \multicolumn{2}{|c|}{$\mathrm{p}$-value } \\
\hline & 1.5 & 2.0 & 2.5 & & Linear & Quadratic \\
\hline \multicolumn{7}{|c|}{ Dry matter intake (g) } \\
\hline Goats & 330 & 454 & 559 & 11.5 & $<0.001$ & 0.665 \\
\hline Sika deer & 316 & 385 & 508 & 61.1 & 0.025 & 0.361 \\
\hline \multicolumn{7}{|c|}{ Digestibility (\%) } \\
\hline \multicolumn{7}{|l|}{ Goats } \\
\hline DM & 77.3 & 70.9 & 67.2 & 1.31 & 0.015 & 0.423 \\
\hline $\mathrm{OM}$ & 79.0 & 72.9 & 69.4 & 1.02 & 0.013 & 0.394 \\
\hline $\mathrm{CP}$ & 83.2 & 77.9 & 76.3 & 1.37 & $<0.001$ & 0.011 \\
\hline NDF & 67.7 & 58.1 & 54.0 & 2.25 & 0.002 & 0.200 \\
\hline \multicolumn{7}{|l|}{ Sika deer } \\
\hline DM & 66.9 & 63.5 & 66.7 & 1.59 & 0.891 & 0.152 \\
\hline $\mathrm{OM}$ & 69.4 & 66.4 & 69.0 & 1.48 & 0.819 & 0.185 \\
\hline$C P$ & 77.6 & 76.3 & 77.0 & 2.17 & 0.814 & 0.704 \\
\hline NDF & 53.0 & 47.8 & 53.2 & 2.38 & 0.983 & 0.159 \\
\hline
\end{tabular}

BW, body weight; SEM, standard error of the mean; DM, dry matter; OM, organic matter; $C$, crude protein; NDF, neutral detergent fiber.

levels. In Sika deer, enteric emission of $\mathrm{CH}_{4}$ expressed as g/d

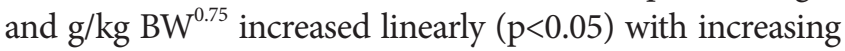

feeding level, while it was not affected by feeding level when expressed as g/kg DMI, g/kg OMI, or \% of GEI. In goats, $\mathrm{CO}_{2}$ production expressed as $\mathrm{g} / \mathrm{d}$ and $\mathrm{g} / \mathrm{kg} \mathrm{BW}{ }^{0.75}$ increased linearly $(\mathrm{p}<0.05)$ with increasing feeding level, and in Sika deer, enteric $\mathrm{CO}_{2}$ production expressed as $\mathrm{g} / \mathrm{kg}$ was not affected by feeding level. However, $\mathrm{CO}_{2}$ production expressed as $\mathrm{g} / \mathrm{kg}$ $\mathrm{BW}^{0.75}$ increased linearly $(\mathrm{p}<0.01)$ with increasing feeding level.

For goats, the model that used the DMI, DM digestibility (DMD), and NDFD as independent variables (equation 1), was most accurate (Table $4 ; \mathrm{R}^{2}=0.69, \mathrm{RMSE}=1.05$, and $\mathrm{p}=$ 0.096), whereas for Sika deer, the model that used the DMI, DMD, and NDFD as independent variables, was most accurate $\left(\mathrm{R}^{2}=0.95, \mathrm{RMSE}=0.98\right.$, and $\left.\mathrm{p}=0.001\right)$.

\section{DISCUSSION}

The amount of feed intake is fundamentally important for animals because it directly affects animal productivity. In general, feeding level and nutrient digestibility in ruminants are negatively correlated $[14,15]$ because a change in feeding level can alter the passage rate and fermentation pattern of the reticulo-rumen [16]. In the current experiment, the nutrient

Table 3. Effect of feeding levels on enteric methane and carbon dioxide in goats (Capra hircus hircus) and Sika deer (Cervus nippon hortulorum)

\begin{tabular}{|c|c|c|c|c|c|c|}
\hline \multirow{2}{*}{ Items } & \multicolumn{3}{|c|}{ Feeding level (\% of BW) } & \multirow{2}{*}{ SEM } & \multicolumn{2}{|c|}{$p$-value } \\
\hline & 1.5 & 2.0 & 2.5 & & Linear & Quadratic \\
\hline \multicolumn{7}{|l|}{ Goats } \\
\hline \multicolumn{7}{|l|}{$\mathrm{CH}_{4}$ production } \\
\hline $\mathrm{CH}_{4}(\mathrm{~g} / \mathrm{d})$ & 8.5 & 10.3 & 11.2 & 0.570 & 0.008 & 0.460 \\
\hline $\mathrm{CH}_{4}\left(\mathrm{~g} / \mathrm{kg} \mathrm{BW} W^{0.75}\right)$ & 0.83 & 0.99 & 1.09 & 0.050 & 0.010 & 0.642 \\
\hline $\mathrm{CH}_{4}(\%$ of GEI) & 9.0 & 8.0 & 7.0 & 0.400 & 0.046 & 0.914 \\
\hline $\mathrm{CH}_{4}(\mathrm{~g} / \mathrm{kg} \mathrm{DMI})$ & 25.7 & 22.7 & 20.1 & 1.13 & 0.047 & 0.912 \\
\hline $\mathrm{CH}_{4}(\mathrm{~g} / \mathrm{kg}$ DDMI) & 33.4 & 32.0 & 30.0 & 1.90 & 0.283 & 0.872 \\
\hline $\mathrm{CH}_{4}(\mathrm{~g} / \mathrm{kg} \mathrm{OMI})$ & 27.9 & 24.6 & 21.9 & 1.23 & 0.047 & 0.913 \\
\hline $\mathrm{CH}_{4}(\mathrm{~g} / \mathrm{kg} \mathrm{DOMI})$ & 35.4 & 33.8 & 31.5 & 1.85 & 0.169 & 0.859 \\
\hline \multicolumn{7}{|l|}{$\mathrm{CO}_{2}$ production } \\
\hline $\mathrm{CO}_{2}(\mathrm{~g} / \mathrm{d})$ & 351 & 435 & 462 & 6.90 & 0.001 & 0.020 \\
\hline $\mathrm{CO}_{2}\left(\mathrm{~g} / \mathrm{kg} \mathrm{BW} W^{0.75}\right)$ & 34.6 & 41.9 & 45.0 & 1.07 & 0.002 & 0.180 \\
\hline \multicolumn{7}{|l|}{ Sika deer } \\
\hline \multicolumn{7}{|l|}{$\mathrm{CH}_{4}$ production } \\
\hline $\mathrm{CH}_{4}(\mathrm{~g} / \mathrm{d})$ & 8.1 & 10.2 & 13.3 & 1.810 & 0.004 & 0.448 \\
\hline $\mathrm{CH}_{4}\left(\mathrm{~g} / \mathrm{kg} \mathrm{BW} W^{0.75}\right)$ & 0.81 & 1.09 & 1.38 & 0.081 & 0.001 & 0.769 \\
\hline $\mathrm{CH}_{4}(\%$ of GEI) & 9.0 & 9.2 & 9.2 & 0.380 & 0.480 & 0.625 \\
\hline $\mathrm{CH}_{4}(\mathrm{~g} / \mathrm{kg} \mathrm{DMI})$ & 25.4 & 26.1 & 26.1 & 1.08 & 0.472 & 0.616 \\
\hline $\mathrm{CH}_{4}(\mathrm{~g} / \mathrm{kg}$ DDMI) & 38.2 & 41.1 & 39.1 & 1.93 & 0.665 & 0.278 \\
\hline $\mathrm{CH}_{4}(\mathrm{~g} / \mathrm{kg} \mathrm{OMI})$ & 27.6 & 28.4 & 28.3 & 1.18 & 0.472 & 0.621 \\
\hline $\mathrm{CH}_{4}(\mathrm{~g} / \mathrm{kg} \mathrm{DOMI})$ & 39.9 & 42.7 & 41.1 & 1.98 & 0.651 & 0.391 \\
\hline \multicolumn{7}{|l|}{$\mathrm{CO}_{2}$ production } \\
\hline $\mathrm{CO}_{2}(\mathrm{~g} / \mathrm{d})$ & 410 & 410 & 489 & 68.4 & 0.141 & 0.278 \\
\hline $\mathrm{CO}_{2}\left(\mathrm{~g} / \mathrm{kg} \mathrm{BW} W^{0.75}\right)$ & 41.7 & 44.4 & 50.7 & 2.17 & 0.006 & 0.228 \\
\hline
\end{tabular}

$\mathrm{BW}$, body weight; $\mathrm{SEM}$, standard error of the mean; $\mathrm{CH}_{4}$, methane; $\mathrm{GEI}$, gross energy intake; DMI, dry matter intake; DDMI, digested dry matter intake; OMI, organic matter intake; DOMI, digested organic matter intake; $\mathrm{CO}_{2}$, carbon dioxide. 
Table 4. Equations for enteric methane emission from goats (Capra hircus hircus) and Sika deer (Cervus nippon hortulorum)

\begin{tabular}{|c|c|c|c|c|}
\hline \multirow{2}{*}{ Items } & \multirow{2}{*}{ Equations } & \multicolumn{3}{|c|}{ Statistical parameters } \\
\hline & & $\mathrm{R}^{2}$ & RMSE & $\mathrm{p}$-value \\
\hline \multicolumn{5}{|l|}{ Goats } \\
\hline 1 & $\mathrm{CH}_{4}(\mathrm{~g} / \mathrm{d})=6.2( \pm 14.1)+10.2( \pm 7.01) \times \mathrm{DMI}(\mathrm{kg} / \mathrm{d})+0.0048( \pm 0.0275) \times \mathrm{DMD}(\mathrm{g} / \mathrm{kg})-0.0070( \pm 0.0187) \times \mathrm{NDFD}(\mathrm{g} / \mathrm{kg})$ & 0.69 & 1.05 & 0.096 \\
\hline 2 & $\mathrm{CH}_{4}(\mathrm{~g} / \mathrm{d})=8.1( \pm 14.1)-10.5( \pm 6.43) \times \mathrm{DMl}(\mathrm{kg} / \mathrm{d})-0.0039( \pm 0.0135) \times \mathrm{DMD}(\mathrm{g} / \mathrm{kg})$ & 0.68 & 0.97 & 0.032 \\
\hline 3 & $\mathrm{CH}_{4}(\mathrm{~g} / \mathrm{d})=4.6( \pm 1.45)+12.1( \pm 3.16) \times \mathrm{DMI}(\mathrm{kg} / \mathrm{d})$ & 0.68 & 0.90 & 0.006 \\
\hline \multicolumn{5}{|c|}{ Sika deer } \\
\hline 4 & $\mathrm{CH}_{4}(\mathrm{~g} / \mathrm{d})=-13.0( \pm 30.8)+29.4( \pm 3.93) \times \mathrm{DMI}(\mathrm{kg} / \mathrm{d})+0.046( \pm 0.094) \times \mathrm{DMD}(\mathrm{g} / \mathrm{kg})-0.0363(0.0636) \times \mathrm{NDFD}(\mathrm{g} / \mathrm{kg})$ & 0.95 & 0.98 & 0.001 \\
\hline 5 & $\mathrm{CH}_{4}(\mathrm{~g} / \mathrm{d})=4.06( \pm 7.49)+27.8( \pm 2.7) \times \mathrm{DMl}(\mathrm{kg} / \mathrm{d})-0.0073( \pm 0.0118) \times \mathrm{DMD}(\mathrm{g} / \mathrm{kg})$ & 0.95 & 0.92 & $<0.001$ \\
\hline 6 & $\mathrm{CH}_{4}(\mathrm{~g} / \mathrm{d})=-0.54( \pm 1.04)+27.4( \pm 2.47) \times \mathrm{DMl}(\mathrm{kg} / \mathrm{d})$ & 0.95 & 0.88 & $<0.001$ \\
\hline
\end{tabular}

RMSE, root mean square error; $\mathrm{CH}_{4}$, methane; DMI, dry matter intake; DMD, dry matter digestibility; NDFD, neutral detergent fiber digestibility.

digestibility of goats decreased linearly $(\mathrm{p}<0.05)$ as feeding level increased. This result was consistent with the findings of previous studies using other ruminants $[14,15,17]$. However, interestingly, nutrient digestibility of Sika deer was not affected by increasing the feeding level. Although a few studies have determined both nutrient digestibility and the DMI of whitetailed and roe deer $[18,19]$, to our knowledge, the effect of feeding level on digestibility has not been previously determined for Sika deer. Nutrient digestibility varies for different species of ruminants [20,21]. Galbraith et al [22] reported that $\mathrm{OM}, \mathrm{NDF}$, and ADF digestibility of white-tailed deer tend to be lower than those of Wapiti. [2,23]. According to the morphophysiological classification of Hofmann [24], Sika deer are classified as concentrate eaters. Therefore, it seems that the nutrient digestibility of Sika deer is different from that of goats and cattle because rumen capacity and retention time of Sika deer are lower than those of both intermediate-type and grass/ roughage eaters. In addition, since the experimental diet of Sika deer in this study was comprised of $50 \%$ roughage sources, it may have been difficult for the deer to digest a large amount of fiber contents due to being concentrate eaters rather than to the feeding levels.

In both goats and Sika deer, enteric emissions of $\mathrm{CH}_{4} \mathrm{ex}$ pressed as $\mathrm{g} / \mathrm{d}$ and $\mathrm{g} / \mathrm{kg} \mathrm{BW}{ }^{0.75}$ increased linearly $(\mathrm{p}<0.05)$ with increasing feeding level, and in goats, enteric production of $\mathrm{CH}_{4}$ expressed as $\mathrm{g} / \mathrm{kg}$ DMI, g/kg OMI, and \% of GEI decreased linearly $(\mathrm{p}<0.05)$ with increasing of feeding level. These results agreed with those of studies that have found that $\mathrm{CH}_{4}$ production ( $\mathrm{g} / \mathrm{kg}$ DMI) decreased with increased feeding level in cows $[25,26]$ and sheep [27]. Because the residence time of rumen contents decreases with increased feed intake, consuming larger amounts of feed can result in shorter exposure time to rumen microbes $[28,29]$. However, enteric production of $\mathrm{CH}_{4}$ expressed as g/kg DMI, g/kg OMI, and \% of GEI were not affected by increasing feeding levels in Sika deer, and, as mentioned above, the morphophysiological differences of the gastro-intestinal tracts of Sika deer can affect rumen capacity and retention time [24]. Consequently, in comparison with both intermediate-type and grass/roughage eaters, it seems that the overall effect of feeding level on enteric $\mathrm{CH}_{4}$ production can be diminished in Sika deer. In both goats and Sika deer, enteric $\mathrm{CH}_{4}$ production expressed as $\mathrm{g} / \mathrm{kg} \mathrm{DDMI}$ and $\mathrm{g} / \mathrm{kg}$ DOMI did not differ statistically. Although digestibility is difficult to measure and requires complex equipment, $\mathrm{Na}$ et al [3] reported that digested nutrient intake is a critical factor that explains $\mathrm{CH}_{4}$ production in goats and Sika deer. Therefore, digested nutrient intake can be used as a $\mathrm{CH}_{4}$ prediction factor when the experimental condition allows. Mineral salt supplementation can influence the enteric methane emission and methanogenic archaea population in rumen [30]. In the current study, mineral block intake did not measure, however, it appears that the effect of mineral block was slight because the animals can freely access to the mineral block.

The models that used nutrient digestibility as a factor exhibited the greatest accuracy in this as well as other experiments $[3,31]$. However, equations 3 and 4 , which used the DMI as the only factor, can also be used to predict enteric $\mathrm{CH}_{4}$ because the model without digestibility is more practical. To our knowledge, only one other study has predicted $\mathrm{CH}_{4}$ production in Sika deer [3]. Therefore, the models evaluated in the current study contribute to our understanding of enteric $\mathrm{CH}_{4}$ emissions in Sika deer.

\section{CONCLUSION}

Nutrient digestibility of goats decreased linearly as the feeding level increased, whereas the digestibility of Sika deer was not affected by feeding level. The enteric production of $\mathrm{CH}_{4}$ expressed as $\mathrm{g} / \mathrm{kg}$ DMI, g/kg OMI, and \% of GEI decreased linearly with increasing feeding levels in goats. However, enteric production of $\mathrm{CH}_{4}$ expressed as $\mathrm{g} / \mathrm{kg} \mathrm{DMI}, \mathrm{g} / \mathrm{kg} \mathrm{OMI}$, and $\%$ of GEI of Sika deer were not affected by feeding level.

\section{CONFLICT OF INTEREST}

We certify that there is no conflict of interest with any financial 
organization regarding the material discussed in the manuscript.

\section{ACKNOWLEDGMENTS}

This work was supported by Korea Institute of Planning and Evaluation for Technology in Food, Agriculture, Forestry and Fisheries (IPET) through Agri-Bio Industry Technology Development Program, funded by Ministry of Agriculture, Food and Rural Affairs (MAFRA) (314010-4).

\section{REFERENCES}

1. Intergovernmental Panel on Climate Change. 2006 IPCC guidelines for national greenhouse gas inventories. Kamiyamaguchi, Japan: Intergovernmental Panel on Climate Change; 2006.

2. Robinson PH, Udén P, Wiseman J, Mateos GG. Some suggestions and guidelines for preparation of manuscripts for submission for consideration for publication. Anim Feed Sci Technol 2007;134:181-8.

3. Na Y, Li DH, Lee SR. Effects of dietary forage-to-concentrate ratio on nutrient digestibility and enteric methane production in growing goats (Capra hircus hircus) and Sika deer (Cervus nippon hortulorum). Asian-Australas J Anim Sci 2017;30:96772.

4. Moe PW, Tyrrell HF. Methane production in dairy cows. J Dairy Sci 1979;62:1583-6.

5. Okine EK, Mathison GW, Hardin RT. Effects of changes in frequency of reticular contractions on fluid and particulate passage rates in cattle. J Anim Sci 1989;67:3388-96.

6. Jeong C-D, Mamuad LL, Kim S-H, et al. Effect of soybean meal and soluble starch on biogenic amine production and microbial diversity using in vitro rumen fermentation. AsianAustralas J Anim Sci 2015;28:50-7.

7. Goodrich RD, Garrett JE, Gast DR, et al. Influence of monensin on the performance of cattle. J Anim Sci 1984;58:1484-98.

8. Shaver RD, Nytes AJ, Satter LD, Jorgensen NA. Influence of amount of feed intake and forage physical form on digestion and passage of prebloom alfalfa hay in dairy cows. J Dairy Sci 1986;69:1545-59.

9. Li DH, Kim BK, Lee SR. A respiration-metabolism chamber system for measuring gas emission and nutrient digestibility in small ruminant animals. Rev Colomb Cienc Pecu 2010;23: 444-50.

10. Omed HM. Studies of the relationships between pasture type and quality and the feed intake of grazing sheep [ $\mathrm{PhD}$ thesis]. Bangor, UK: University College of North Wales; 1986.

11. Gardinal R, Calomeni GD, Cônsolo NRB, et al. Influence of polymer-coated slow-release urea on total tract apparent digestibility, ruminal fermentation and performance of Nellore steers. Asian-Australas J Anim Sci 2017;30:34-41.
12. AOAC International, Cunniff P. Official methods of analysis of AOAC International. Arlington, VA: AOAC International; 1995.

13. Van Soest PJ, Robertson JB, Lewis BA. Methods for dietary fiber, neutral detergent fiber, and nonstarch polysaccharides in relation to animal nutrition. J Dairy Sci 1991;74:3583-97.

14. Blaxter KL, Wainman FW. The utilization of food by sheep and cattle. J Agric Sci 1961;57:419-25.

15. Watson CJ, Davidson WM, Kennedy JW, Robinson CH, Muir GW. Digestibility Studies with ruminants: XII. The comparative digestive powers of sheep and steers. Sci Agric 1948;28:357-74.

16. Terry RA, Tilley JMA. Volatile fatty acid determinations on sheep rumen liquor. Exp Prog Grassld Res Inst 1961;13:79-80.

17. Fenner H, Dickinson FN, Barnes HD. Relationship of digestibility and certain rumen fluid components to level of feed intake and time of sampling after feeding. J Dairy Sci 1967;50: 334-44.

18. Ammann AP, Cowan RL, Mothershead CL, Baumgardt BR. Dry matter and energy intake in relation to digestibility in white-tailed deer. J Wildl Manage 1973;2:195-201.

19. Drożdż A, Osiecki A. Intake and digestibility of natural feeds by roe-deer. Acta Theriol (Warsz) 1973;18:81-91.

20. Koch RM, Jung HG, Crouse JD, Varel VH, Cundiff LV. Growth, digestive capability, carcass, and meat characteristics of Bison bison, Bos taurus, and Bos $\times$ Bison. J Anim Sci 1995;73:1271-81.

21. Richmond RJ, Hudson RJ, Christopherson RJ. Comparison of forage intake and digestibility by bison, yak and cattle [Internet]. Agric Bull; 1976. Available from: http://agris.fao.org/agrissearch/search.do?recordID=CA19770190262

22. Galbraith JK, Mathison GW, Hudson RJ, McAllister TA, Cheng K-J. Intake, digestibility, methane and heat production in bison, wapiti and white-tailed deer. Can J Anim Sci 1998;78:681-91.

23. Islam M, Abe H, Hayashi $Y$, Terada F. Effects of feeding Italian ryegrass with corn on rumen environment, nutrient digestibility, methane emission, and energy and nitrogen utilization at two intake levels by goats. Small Rumin Res 2000;38:165-74.

24. Hofmann RR. Evolutionary steps of ecophysiological adaptation and diversification of ruminants: a comparative view of their digestive system. Oecologia 1989;78:443-57.

25. Sauvant D, Giger-Reverdin S. Variations in the production of $\mathrm{CH}_{4}$ per unit of digestible organic matter intake. Proc XIe ISRP; 2009. pp. 350-1.

26. Beauchemin KA, McGinn SM. Enteric methane emissions from growing beef cattle as affected by diet and level of intake. Can J Anim Sci 2006;86:401-8.

27. Blaxter KL, Clapperton JL. Prediction of the amount of methane produced by ruminants. Br J Nutr 1965;19:511-22.

28. Dewhurst RJ, Evans RT, Scollan ND, et al. Comparison of grass and legume silages for milk production. 2. In vivo and in sacco evaluations of rumen function. J Dairy Sci 2003;86:2612-21.

29. Pinares-Patiño CS, Waghorn GC, Machmüller A, et al. Methane emissions and digestive physiology of non-lactating dairy cows 
fed pasture forage. Can J Anim Sci 2007;87:601-13.

30. Li X, Liu C, Chen Y, et al. Effects of mineral salt supplement on enteric methane emissions, ruminal fermentation and methanogen community of lactating cows. Anim Sci J 2017;88: 1049-57.
31. Patra AK, Lalhriatpuii M. Development of statistical models for prediction of enteric methane emission from goats using nutrient composition and intake variables. Agric Ecosyst Environ 2016;215:89-99. 